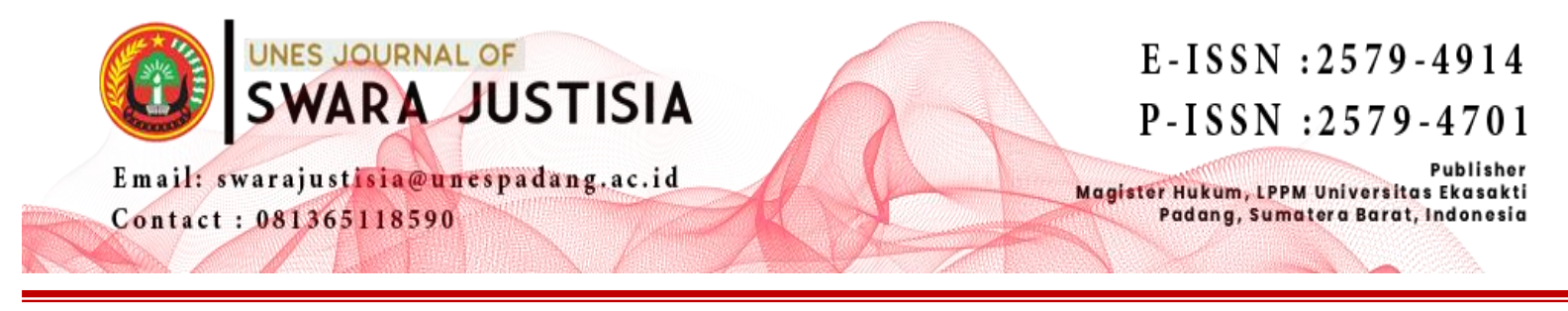

\title{
PERSPEKTIF KEBIJAKAN KRIMINAL DALAM UPAYA PENANGGULANGAN TINDAK PIDANA NARKOTIKA DI INDONESIA
}

\author{
Daeng Rahman \\ Program Magister Ilmu Hukum, Universitas Ekasakti, Padang, Indonesia \\ Email: daengmarun@gmail.com
}

\begin{abstract}
The current criminal policy in tackling narcotics crime in Indonesia is the enactment of Law Number 35 of 2009 concerning Narcotics. Most of the criminal sanctions in the Narcotics Law are formulated cumulatively. The inclusion of minimal criminal threats. Unclear regulations regarding corporate criminal acts. Criminal Policy Perspective in Combating Narcotics Crime in Indonesia must be carried out in accordance with the basic concepts of criminalization. The development of the provisions of the narcotics crime can be found in the draft Criminal Code with the idea of recodification. The RKUHP formulation should have been done by evaluating the implementation of the law that has been carried out so far. But in fact, the provisions regarding narcotics crime in the Chapter "Special Crimes" are only done by copying and pasting the formulation of the criminal provisions in the Narcotics Law (Narcotics Law). The RKUHP does not clearly regulate the administrative aspects that are the core of the Narcotics Law, such as guarantees of rehabilitation for narcotics addicts and victims of drug abusers. The accommodation of narcotics crime in the RKUHP emphasizes that the approach used by the State in dealing with narcotics problems is a criminal approach not a public health approach.
\end{abstract}

Keywords: Crime, Narcotics, Perspective, Criminal Policy

\begin{abstract}
ABSTRAK
Kebijakan pidana saat ini dalam menanggulangi tindak pidana narkotika di Indonesia adalah dengan diundangkannya Undang-Undang Nomor 35 Tahun 2009 tentang Narkotika. Sebagian besar sanksi pidana dalam UU Narkotika dirumuskan secara kumulatif. Pencantuman ancaman pidana minimal. Peraturan yang tidak jelas mengenai tindak pidana korporasi. Perspektif Kebijakan Pidana dalam Pemberantasan Tindak Pidana Narkotika di Indonesia harus dilaksanakan sesuai dengan konsep dasar kriminalisasi. Perkembangan ketentuan pidana narkotika dapat ditemukan dalam Rancangan KUHP dengan gagasan rekodifikasi. Penyusunan RKUHP seharusnya dilakukan dengan mengevaluasi pelaksanaan undang-undang yang telah dilakukan selama ini. Namun pada kenyataannya ketentuan mengenai tindak pidana narkotika dalam Bab "Tindak Pidana Khusus" hanya dilakukan dengan menyalin dan menempelkan rumusan ketentuan pidana dalam Undang-Undang Narkotika (UU Narkotika). RKUHP tidak mengatur secara jelas aspek administrasi yang menjadi inti dari UU Narkotika, seperti jaminan rehabilitasi bagi pecandu narkotika dan korban penyalahguna narkoba. Akomodasi kejahatan narkotika dalam RKUHP menekankan bahwa pendekatan yang digunakan oleh Negara dalam menangani masalah narkotika adalah pendekatan pidana bukan pendekatan kesehatan masyarakat.
\end{abstract}


Kata Kunci: Kejahatan, Narkotika, Perspektif, Kebijakan Pidana

\section{PENDAHULUAN}

Ditinjau dari aspek kepentingan nasional, konvensi ini dapat menjamin kepastian dan keadilan hukum dalam upaya penegakan hukum peredaran gelap narkotika dan psikotropika yang melibatkan para pelaku kejahatan lintas batas teritorial Indonesia. Di samping itu untuk kepentingan nasional, khususnya untuk kepentingan didalam negeri, akan diperoleh suatu kepastian dan kemanfaatan dalam rangka pengaturan peredaran narkotika dan psikotropika untuk kepentingan pengobatan dan ilmu pengetahuan. ${ }^{1}$

Ketentuan perundang-undangan yang mengatur masalah narkotika dan psikotropika telah disusun dan diberlakukan, namun demikian kejahatan yang menyangkut narkotika dan psikotropika ini belum dapat diredakan. Dalam kasus kasus terakhir telah banyak bandarbandar dan pengedar narkoba tertangkap dan mendapat sanksi berat, namun pelaku yang lain seperti tidak mengacuhkan bahkan lebih cenderung untuk memperluas daerah operasinya. ${ }^{2}$

Penegakan hukum terhadap kejahatan di Indonesia, khususnya dalam hal pemidanaan, seharusnya merujuk pada pendekatan norma hukum yang bersifat membina penjahat dengan cara melakukan pembinaan di lembaga pemasyarakatan, dengan demikian dapat memberpaiki terpidana di lembaga pemasyarakatan tersebut. Seharusnya hal ini mampu memberikan wacana kepada para hakim dalam merumuskan vonis penjatuhan pidana kepada para pelaku kejahatan agar mampu menangkap aspirasi keadilan masyarakat. Sementara itu, dalam kenyataan empiris di bidang pemidanaan secara umum masih menganut konsep hanya menghukum terpidana di lembaga pemasyarakatan, dengan demikian dapat memberikan gambaran bahwa kejahatan tersebut hanya terhenti sesaat dan akan muncul kembali dalam lingkungan kehidupan sosial masyarakat.

Penegakan hukum terhadap kejahatan di Indonesia yang mana pemerintah selaku penyelenggara kehidupan bernegara perlu memberikan perlindungan dan kesejahteraan masyarakat melalui berbagai kebijakan yang teragenda dalam program pembangunan nasional. Kebijakan pemerintah ini tergabung dalam kebijakan sosial (social policy). Salah satu bagian dari kebijakan sosial ini adalah kebijakan penegakan hukum (law enforcement policy), termasuk di dalamnya kebijakan legislatif (legislative policy). Sedangkan kebijakan penanggulangan kejahatan (criminal policy) itu sendiri merupakan bagian dari kebijakan penegakan hukum (law enforcement policy). ${ }^{3}$

Pengkajian mengenai penegakan hukum pidana, dapat dilihat dari cara penegakan hukum pidana yang dikenal dengan sistem penegakan hukum atau criminal law enforcement yang mana bagiannya adalah kebijakan penanggulangan kejahatan (criminal policy). Dalam penanggulangan kejahatan dibutuhkan dua sarana yakni menggunakan penal atau sanksi pidana, dan menggunakan sarana non penal yaitu penegakan hukum tanpa menggunakan sanksi pidana (penal). Penegakan hukum mempunyai sasaran agar orang taat kepada hukum.

\footnotetext{
${ }^{1}$ Siswantoro Sunarso, Penegakan Hukum Dalam Kajian sosiologis, Raja Grafindo Persada, Jakarta, 2004, hlm. 1.

2 O.C. Kaligis \& Associates, Narkoba dan Peradilannya di Indonesia, Reformasi Hukum Pidana Melalui Perundangan dan Peradilan, Alumni, Bandung, 2002, hlm. 260.

${ }^{3}$ Mahmud Mulyadi, Politik Hukum Pidana, Bahan-bahan kuliah Fakultas Hukum Universitas Sumatera Utara, Medan, 2011, hlm. 6.
} 
Ketaatan masyarakat terhadap hukum disebabkan tiga hal, yakni: (1) takut berbuat dosa; (2) takut karena kekuasaan dari pihak penguasa berkaitan dengan sifat hukum yang bersifat imperatif; (3) takut karena malu berbuat jahat. Penegakan hukum dengan sarana non penal mempunyai sasaran dan tujuan untuk kepentingan internalisasi. ${ }^{4}$

Keberadaan Undang-Undang Narkotika yakni Undang-Undang Nomor 35 Tahun 2009 tentang Narkotika merupakan suatu upaya politik hukum pemerintah Indonesia terhadap penanggulangan tindak pidana narkotika. Pembentukan undang-undang narkotika diharapkan dapat menanggulangi peredaran gelap dan penyalahgunaan narkotika dengan menggunakan sarana hukum pidana atau penal.

Diharapkan dengan dirumuskanya undang-undang tersebut dapat menanggulangi peredaran gelap dan penyalahgunaan narkotika, serta menjadi acuan dan pedoman kepada pengadilan dan para penyelenggara atau pelaksana putusan pengadilan yang menerapkan undang-undang, khususnya hakim dalam menjatuhkan sanksi pidana terhadap kejahatan yang terjadi. Dalam penelitian ini, penulis akan mencoba meneliti tentang kebijakan hukum pidana yang tertuang dalam Undang-Undang Narkotika serta implementasinya dalam penangulangan tindak pidana narkotika .

Berdasarkan latar belakang pemikiran di atas, maka permasalahan adalah Kebijakan kriminal dalam penanggulangan tindak pidana narkotika di Indonesia saat ini dan perspektifmya.

\section{METODE PENELITIAN}

Spesifikasi penelitian adalah deskriptif analitis, dengan metode pendekatan yuridis normative. Jenis data yang digunakan adalah data sekunder. Data sekunder diperoleh dari studi dokumen dan studi kepustakaan. Data yang diperoleh kemudian dianalisa secara kualitatif.

\section{PEMBAHASAN}

\section{A. Kebijakan Kriminal Dalam Penanggulangan Tindak Pidana Narkotika Di Indonesia Saat Ini}

Saat ini di Indonesia berlaku Undang-Undang Nomor 35 Tahun 2009 tentang Narkotika (Lembaran Negara Tahun 2009 Nomor: 143), tanggal 12 Oktober 2009, yang menggantikan Undang-Undang No. 22 Tahun 2007 tentang Narkotika (lembaran Negara Tahun 2007 Nomor 67), karena sebagaimana pada bagian menimbang dari UndangUndang Nomor 35 Tahun 2009 huruf e dikemukakan: bahwa tindak pidana Narkotika telah bersifat transnasional yang dilakukan dengan menggunakan modus operandi yang tinggi, teknologi canggih, didukung oleh jaringan organisasi yang luas, dan sudah banyak menimbulkan korban, terutama di kalangan generasi muda bangsa yang sangat membahayakan kehidupan masyarakat, bangsa, dan Negara, sehingga UndangUndangNomor 22 Tahun 1997 tentang Narkotika sudah tidak sesuai lagi dengan perkembangan situasi dan kondisi yang berkembang untuk menanggulangi dan memberantas Tindak Pidana tersebut. Oleh sebab itu, berdasarkan ketentuan 153 Undang

\footnotetext{
${ }^{4}$ Siswantoro Sunarso, Penegakan Hukum Dalam Kajian Sosiologis, Raja Grafindo Persada, Jakarta, 2004, hlm. 142
} 
Undang Nomor 35 Tahun 2009, bahwa dengan berlakunya Undang Undang Nomor 35 Tahun 2009, maka Undang-Undang Nomor 22 Tahun 1997 dicabut dan dinyatakan tidak berlaku. Undang-Undang Nomor 35 Tahun 2009 disahkan pada 14 September 2009 merupakan revisi dari Undang-Undang No. 22 Tahun 1997 tentang Narkotika. Pemerintah menilai Undang-Undang No. 22 Tahun 1997 ini tidak dapat mencegah tindak pidana narkotika yang semakin meningkat secara kuantitatif maupun kualitatif serta bentuk kejahatannya yang terorganisir. Namun secara substansial, Undang-Undang Narkotika yang baru tidak mengalami perubahan yang signifikan dibandingkan dengan Undang-Undang terdahulu, kecuali penekanan pada ketentuan kewajiban rehabilitasi, penggunaan pidana yang berlebihan, dan kewenangan BNN yang sangat besar.

Berangkat dari permasalahan di atas maka dalam Undang-Undang Narkotika sendiri perlulah memiliki suatu kebijakan tertulis mengenai tindak pidana yang berkaitan dengan penyalahgunaan narkotika itu sendiri. Ketentuan Pidana di dalam UndangUndang Nomor 35 tahun 2009 tentang Narkotika terdapat pada Bab XV Ketentuan Pidana yaitu pada Pasal 111 sampai Pasal 148.

Undang-undang narkotika dan psikotropika tidak membahas mengenai pengertian tindak pidana narkotika dan psikotropika, namun atas dasar penegrtian dan penejlasan tentang tindak pidana di atas, akan membantu dalam memberikan pengertian tentang tindak pidana narkotika dan psikotropika yang tentu saja tetap mengacu pada ketentuanketentuan yang terdapat dalam Undang-undang Nomor 5 tahun 1997 tentang Psikotropika. Untuk mempermudah pemahaman atas pengertian tentang tindak pidana narkotika dan psikotropika maka terlebih dahulu akan dijelaskan perbedaan istilah hukuman dan pidana. Dalam sistem hukum, bahwa hukum atau pidana yang dijatuhkan adalah menyangkut tentang perbuatan-perbuatan apa yang diancam pidana, haruslah terlebih dahulu telah tercantum dalam Undang-Undang Hukum Pidana, jika tidak ada Undang-undang yang mengatur, maka pidana tidak dapat dijatuhkan.

Menurut Undang-Undang Narkotika, dalam hal tindak pidana dilakukan oleh korporasi selain pidana penjara dan denda terhadap pengurusnya, pidana yang dapat dijatuhkan terhadap korporasi berupa pidana denda dengan pemberatan 3 (tiga) kali dari pidana denda sebagaimana dimaksud dalam Pasal 111 s.d Pasal 126 dan Pasal 129. Korporasi dapat juga dijatuhi pidana tambahan berupa Pencabutan izin usaha; dan/atau Pencabutan status badan hukum.

Sehubungan dengan aspek penal (hukum pidana) dalam rangka upaya penanggulangan tindak pidana narkotika melalui ketentuan Undang-undang No. 35 Tahun 2009 Tentang Narkotika, perangkat globalisasi yang juga digunakan dalam pemberantasan tindak pidana narkotika melalui Undang-undang Republik Indonesia No. 8 Tahun 1976 tentang Pengesahan konvensi Tunggal Narkotika 1961 beserta protokol tahun 1972 yang mengubahnya dan Undang-undang Republik Indonesia No. 7 Tahun 1997 tentang Pengesahan Konvensi Perserikatan Perserikatan Bangsa-Bangsa tentang Pemberantasan Peredaran gelap Narkotika dan Psikotropika, 1988.

Kriminalisasi terhadap narkotika dalam Undang-Undang No. 35 Tahun 2009 proses penegakkannya akan dijalankan melalui mekanisme Sistem Peradilan Pidana (Criminal Justice System). Keadilan yang ingin diwujutkan melalui SPP adalah Keadilan Retributif (Retributif Justice) dan Just Desert Model (balasan yang setimpal). Dalam 
konteks Indonesia Penegakan Hukum Pidana harus memperhatikan rambu-rambu Hukum Nasional yang berfungsi sebagai Legal Frame work sebagaimana diatur dalam Undang-Undang Dasar 1945 dan Undang-Undang Pokok Kekuasaan Kehakiman. Oleh karena itu penegakan hukum pidana tidak hanya diartikan sebagai Legal certainty akan tetapi juga Substantif certainty.

Penegakan hukum ini diharapkan mampu sebagai faktor penangkal terhadap merebaknya peredaran perdagangan narkotika. Dengan semakin merebaknya penyalahgunaan narkotika yang berdampak negatif pada kehidupan masyarakat. Sehingga, untuk mengendalikan dan mengembalikan kondisi kehidupan masyarakat yang ideal (tertib, aman, dan tentram) diperlukan peran Polri. Sebagaimana diatur dalam Pasal 13 Undang-Undang Nomor 2 Tahun 2002 Tentang Kepolisian Negara Republik Indonesia.

\section{B. Perspektif Kebijakan Kriminal Dalam Penanggulangan Tindak Pidana Narkotika Di Indonesia}

Secara teoritis kebijakan krimiminalisasi terhadap penyalahgunaan narkotika berangkat dari pemikiran yang dikemukakan oleh Peter Hoefnagels bahwasanya: Teori G. Peter Hoefnagels yang menyatakan bahwa "Criminal policy is the rational organization of social reactions to crime." 5 Teori ini merupakan perumusan kembali dari teori Marc Ancel yang menyatakan bahwa "criminal policy is the rational organization of the control of crime by society" (upaya rasional dari masyarakat dalam menanggulangi kejahatan). ${ }^{6}$

Berdasarkan kerangka pemikiran teoritis diatas, maka penanggulangan terhadap penyalahgunaan narkotika akan dapat ditempuh melalui dua aspek yakni dengan aspek penal (hukum pidana). Aspek Penal, diawali dengan analisis terhadap ketentuan perundang-undangan pidana yang berkaitan dengan narkotika dan psikotropika khususnya terhadap kebijakan hukum pidana (penal policy), melalui kajian normatif yang merupakan tahap kebijakan legislatif. Kajian selanjutnya dilakukan dengan mengamati pelaksanaan ketentuan perundang-undangan pidana (in abstrakto) narkotika dan psikotropika ke perundangundangan pidana (in konkrito) melalui mekanisme sistem peradilan pidana terpadu yang merupakan tahap kebijakan aplikatief yang selanjutnya akan diteruskan pada tahap kebijakan eksekutif. Temuan dari analisis hasil penelitian aspek penal terhadap narkotika dan psikotropika, merupakan bahan masukan untuk melakukan perbaikan dalam perencanaan penanggulangan penyalahgunaan narkotika dikemudian hari.

Kebijakan kriminal terhadap narkotika di Indonesia harus dilakukan sesuai dengan konsep-konsep dasar kriminalisasi. Kebijakan kriminal ini harus merupakan bagian dari kebijakan sosial atau kebijakan pembangunan nasional. Penegasan bahwa antara upaya penanggulangan kejahatan dan perencanaan sosial perlu terintegrasi dalam keseluruhan kebijakan sosial sosial dan perencanaan pembangunan. Sudarto menyatakan

5 A. R. Sujono, Komentar dan Pembahasan Undang- undang. Nomor 35 Tahun 2009 Tentang Narkotika, Sinar grafika, Jakarta, 2013, hlm. 61-62.

${ }^{6}$ Marc Ancel, Social Defence; A Modern Approach to Criminal Problem, Routledge and Kegan Paul, London, 1965, hlm 208-209 
bahwa apabila hukum pidana hendak dilibatkan dalam usaha mengatasi segi-segi negatif dari perkembangan masyarakat (modernisasi), maka hendaknya dilihat dalam hubungan keseluruhan politik kriminal atau social defence planing, dan inipun harus merupakan bagian integral dari perencanaan pembangunan nasional. ${ }^{7}$

Dalam hal penanggulangan tindak pidana narkotika yang sangat erat kaitannya dengan kebijakan sosial. Selain itu kebijakan ini juga harus disesuaikan dengan kebutuhan yang ingin dicapai dan kondisi sosial budaya Indonesia, walaupun terdapat kreteria yang diatur suatu pedoman namun tetap saja ada suatu nilai yang sesuai dengan jiwa bangsa Indonesia. Konsep hukum seperti ini sesuai dengan pendapat Von Savigny yang menyatakan bahwa pada intinya hukum itu terdiri dari unsur politis (das politische element) dan unsur teknis (das technische element). Unsur politis artinya bahwa isi hukum itu adalah pencerminan jiwa bangsa maknanya ada keterkaitan yang mendalam atas isi hukum itu dengan keyakinan-keyakinan bangsa atau jiwa bangsa (volk geist), sedang unsur teknis adalah bahwa mengenai pengolahan hukum diserahkan kepada kaum juris yang merupakan para ahli dalam bidang itu. Jeremy Bentham menyatakan bahwa tujuan hukum itu harus berguna bagi masyarakat untuk mencapai kebahagiaan sebesarbesarnya. Ide pokok dari Bentham masyarakat harus diatur dengan baik, kalau institusiinstitusi yang berkepentingan dibentuk sedemikian rupa sehingga menghasilkan kepuasan yang sebesar mungkin bagi semua orang termasuk masyarakat itu. ${ }^{8}$

Kebijakan Hukum Pidana dalam Undang-Undang Republik Indonesia Nomor 35 Tahun 2009 Tentang Narkotika merupakan kebijakan penal dalam undang-undang itu antara lain dapat diidentifikasikan sebagai kebijakan kriminalisasi dari Undang-Undang Narkotika terfokus pada penyalahgunaan dan peredaran "narkoba"nya (mulai dari penanaman, produksi, penyaluran, lalu lintas, pengedaran sampai ke pemakaiannya, termasuk pemakaian pribadi), tidak pada kekayaan ("property/assets") yang diperoleh dari tindak pidana "narkoba"nya itu sendiri.

Kebijakan kriminalisasi demikian memang sesuai dengan konvensi PBB mengenai narkotika dan Psikotropika. Namun, sebenarnya kebijakan kriminalisasi menurut konvensi PBB tidak hanya itu, Khususnya untuk narkotika. Konvensi PBB juga menyatakan agar dijadikan/ditetapkan sebagai suatu tindak pidana, perbuatan "mengubah atau mengalihkan/menstransfer kekayaan yang diketahuinya berasal dari tindak pidana narkotika atau berasal dari keikutsertaan melakukan tindak pidana itu, untuk tujuan menyembunyikan asal usul gelap dari kekayaan itu atau untuk tujuan membantu seseorang menghindari akibat-akibat hukum dari keterlibatannya melakukan tindak pidana itu. Rumusan tindak pidana seperti di atas tidak ada dalam Undang-Undang Narkotika (Nomor 35 Tahun 2009). Namun saat ini sudah dimasukkan dalam UndangUndang Nomor 15 Tahun 2002 tentang Tindak Pidana Pencucian Uang (Money Laundering). Hanya patut dicatat, bahwa menurut UndangUndang Nomor 15 Tahun 2002 (Pasal 2) ada pembatasan jumlah/nilai uang atau harta kekayaan yang dicuci, yaitu Rp. 500.000.000,-(lima ratus juta rupiah) atau lebih. Pembatasan ini dapat juga mempengaruhi efektivitas penegakan hukumnya karena tidak mustahil dapat digunakan

\footnotetext{
${ }^{7}$ Sudarto, Hukum dan Hukum Pidana, Alumni, Bandung, 1977, hlm. 38.

${ }^{8}$ Theo Huijbers, Filsafat Hukum Dalam Lintas Sejarah, Penerbit Yayasan Kanisius, Bandung, 1982,
} hlm. 118. 
sebagai celah-celah untuk lolos dari jaringan hukum dengan jalan memecah-mecah uang yang dicuci itu dibawah nilai Rp. 500.000.000,- (lima ratus juta rupiah).

Kitab Undang-undang Hukum Pidana (KUHP) di Indonesia yang digunakaan saat ini adalah warisan dari pemerintah Hindia Belanda yang diberlakukan melalui aturan Undang Undang Nomor 1 tahun 1946 tentang Peraturan Hukum Pidana. Pada 5 Juni 2015, melalui Surat Presiden RI R-35/Pres/06/2015 pemerintah memulai pembahasan Rancangan KUHP (RKUHP) dengan DPR. Pada 30 Mei 2018, Rapat antara Pemerintah dan DPR dengan agenda pembahasan rekomendasi rumusan dari Pemerintah, Rapat tersebut menghasilkan draft 28 Mei 2018 kemudian mengalami perubahan dengan dratf terakhir tahun 2019.

Sebelumnya pada draft pertama yang diserahkan DPR pada 2015, tindak pidana narkotika diletakkan pada Bab XVII tentang Tindak Pidana Penyalahgunaan Narkotika dan Psikotropika setelah Bab XVI tentang Kesusilaan. Sejak awal tahun 2018 mulai digulirkanlah proposal yang menyatakan bahwa pengaturan tindak pidana di luar KUHP dalam RKUHP sebagai konsep rekodifikasi. Namun pemeritah dan DPR secara berkalikali menyatakan bahwa tindak pidana yang sudah diatur diluar KUHP yang dimuat dalam RKUHP hanya core crimes saja atau kejahatan inti, dengan sebutan "hanya cantolan". Dan akhirnya ketentuan mengenai tindak pidana narkotika dimasukkan ke dalam bab "Tindak Pidana Khusus".

Dengan ide rekodifikasi, harusnya perumusan RKUHP dilakukan dengan mengevaluasi penerapan UU yang selama ini dilakukan. Namun nyatanya, ketentuan mengenai tindak pidana narkotika dalam Bab "Tindak Pidana Khusus" hanya dilakukan dengan salin-tempel rumusan ketentuan pidana dalam UU Narkotika (UU Narkotika). Salah satu akibatnya adalah RKUHP tidak mampu menjangkau pengaturan ketentuanketentuan teknis dalam UU Narkotika, sehingga menjadi membingungkan ketika rumusan tindak pidana narkotika disalin dalam dalam RKUHP tanpa mengatur secara jelas aspek administrasi yang menjadi inti UU Narkotika, seperti jaminan rehabilitasi bagi pecandu narkotika dan korban penyalahguna narkotika. Di sisi yang lain, diakomodirnya tindak pidana narkotika dalam RKUHP justru secara jelas menegaskan bahwa pendekatan yang digunakan Negara dalam menangani masalah narkotika adalah dengan pendekatan pidana bukan dengan pendekatan kesehatan masyarakat.

Seharusnya upaya pembaruan hukum pidana yang saat ini dilakukan antara pemerintah dan DPR dapat menjamin hak-hak asasi manusia yang dijamin dalam UUD 1945 dan berbagai komitmen internasional yang telah disepakati oleh Negara Republik Indonesia. Terkhusus mengenai masalah narkotika harus ditekankan pada perlindungan korban dari narkotika itu sendiri. Baik melalui perspektif kesehatan masyarakat maupun memastikan tidak ada pasal dalam RKUHP yang dapat mengkriminalisasi korban narkotika.

\section{KESIMPULAN}

Agar dilakukan penyusunan perundang undang tindak pidana narkotika yang lebih mempunyai kepastian hukum bukannya kebanyakan pasal pasal bersifat karet dan multi tafsir. Pembaharuan terhadap kebijakan kriminal bagi penyalahgunaan narkotika secara 
khusus dalam perundang undangan tersendiri tanpa menggabungkan dengan ketentuan hukum pidana lain.

\section{DAFTAR PUSTAKA}

\section{Buku-Buku:}

Siswantoro Sunarso, Penegakan Hukum Dalam Kajian sosiologis, Raja Grafindo Persada, Jakarta, 2004.

O.C. Kaligis \& Associates, Narkoba dan Peradilannya di Indonesia, Reformasi Hukum Pidana Melalui Perundangan dan Peradilan, Alumni, Bandung, 2002.

Mahmud Mulyadi, Politik Hukum Pidana, Bahan-bahan kuliah Fakultas Hukum Universitas Sumatera Utara, Medan, 2011

Siswantoro Sunarso, Penegakan Hukum Dalam Kajian Sosiologis, Raja Grafindo Persada, Jakarta, 2004

A. R. Sujono, Komentar dan Pembahasan Undang- undang. Nomor 35 Tahun 2009 Tentang Narkotika, Sinar grafika, Jakarta, 2013.

Marc Ancel, Social Defence; A Modern Approach to Criminal Problem, Routledge and Kegan Paul, London, 1965

Sudarto, Hukum dan Hukum Pidana, Alumni, Bandung, 1977

Theo Huijbers, Filsafat Hukum Dalam Lintas Sejarah, Penerbit Yayasan Kanisius, Bandung, 1982.

\section{Perturan Perundangan-Undangan:}

Undang Undang Nomor 1 tahun 1946 tentang Peraturan Hukum Pidana.

Undang-undang Republik Indonesia No. 8 Tahun 1976 tentang Pengesahan konvensi Tunggal Narkotika.

Undang-Undang No. 22 Tahun 1997 tentang Narkotika

Undang-Undang Nomor 2 Tahun 2002 Tentang Kepolisian Negara Republik Indonesia.

Undang-Undang Nomor 35 Tahun 2009 tentang Narkotika 